\title{
eWOM and Decision Making on the Use of e-Wallet Application By Indonesian Customers
}

\author{
Nindyta Aisyah Dwityas ${ }^{1}$, Rizki Briandana ${ }^{2}$, Rohana Mijan $^{3}$, Richard $^{4}$, \\ Diah Wardhani ${ }^{5}$
}

Abstract:

Purpose: The purpose of this study is to measure the effect of electronic word of mouth on the decision-making process of transactions using the LinkAja application.

Design/Methodology/Approach: This study was conducted with an explanative quantitative approach.

Findings: The result of the study shows that the electronic word of mouth variable had a significant influence on the variable of purchasing decision-making process using the LinkAja application.

Practical Implications: Promoting positive electronic word-of-mouth about the benefits and values of the financial technology usage especially in community-based media discussions is crucial to encourage the use of digital wallet applications.

Originality/Value: The results of this study revealed the percentage of how electronic word of mouth has been influencing the decision-making process of using the LinkAja application as a means of transaction. This pecentage is obtained through analysis using a regression test on the distribution of responses from a sample of millennial generation of members of the Facebook Mobile Legend: Bang Bang Indonesia community.

Keywords: Customer, decision-making, e-Wallet, e-WOM, Bang Bang Indonesia.

JEL classification: D8, M31, M31, M37

Paper Type: Research article.

Acknowledgments: The authors would like to thank the Directorat Research Universitas Mercu Buana, and School of Multimedia \& Technology Communication, Universiti Utara Malaysia for the collaboration research.

\footnotetext{
${ }^{1}$ Fakultas Ilmu Komunikasi, Universitas Mercu Buana, nindyta.aisyah@mercubuana.ac.id,

${ }^{2}$ Fakultas Ilmu Komunikasi, Universitas Mercu Buana, rizki.briandana@mercubuana.ac.id,

${ }^{3}$ School of Multimedia \& Technology Communication, Universiti Utara Malaysia, rohana.mijan@uum.my,

${ }^{4}$ Fakultas Imu Komunikasi, Universitas Mercu Buana, inosensius.thio@gmail.com

${ }^{5}$ Fakultas Ilmu Komunikasi, Universitas Mercu Buana, diah.wardhani@mercubuana.ac.id;
} 


\section{Introduction}

The development of digital technology affects all aspects of human life including communication (Fan, Liu, Wang, and Wang, 2017). The use of technology, especially the internet, can change the way consumers communicate and share opinions or reviews about products or services they have consumed (Goldsmith and Horowitz, 2006). The activity of sharing information or consumer consumption results carried out through online platforms is also known as electronic word of mouth (e-WOM) (Jalilvand, Esfahani, and Samiei, 2011). Electronic word of mouth is a form of adaptation or adjustment to changes and developments at this time (Fan and Miao, 2012). The internet is an important facility in the evolution of word of mouth into electronic word of mouth where consumers share information through digital media or the internet (Liu et al., 2015).

The activity of sharing information via the internet or electronic word of mouth is nothing new (Hennig-Thurau, Gwinner, Walsh, and Gremler, 2004). It is recorded that in Indonesia alone there are $74.84 \%$ of people who depend on the use of information search engines to obtain various information (Bohang, 2018). Indonesians mostly use the internet to find information about prices $(45.14 \%)$, to help with jobs $(41.04 \%)$, purchase information (37.82\%), online shopping $(32.19 \%)$, to find work $(26,19)$, conducting banking transactions $(17.04 \%)$ and online sales $(16.83 \%)$. The data prove that many Indonesians use the internet to get information about a product or company (Bohang, 2018).

Information obtained through various online platforms can be useful for other consumers who intend to buy a product (Dwityas, Mulyana, Hesti, Briandana, and Putrianti, 2020) Consumers tend to seek more detailed information for products that have high involvement and one of the products that have high involvement is banking (Shaikh, Glavee-Geo, and Karjaluoto, 2017).

Banking is a product that has a high risk. For this reason, it requires information and long thoughts before consumers choose various banking products (Dasho, Meka, Sharko, and Baholli, 2016). Banking is a financial institution that has three main functions, i.e. to raise, channel funds, and provide other bank services (Homsi et al., 2020). To improve these three functions, banks continue to innovate by utilizing technology. Currently, the banking industry is starting to face new threats and opportunities simultaneously due to the use of digital technology by other companies that aim to outperform retail banking services (Al-Dmour, Asfour, Al-Dmour, and Al-Dmour, 2020).

In response to this phenomenon, the banking business in general has started to make innovative efforts through digitization. Jahja Setiaatmaja as President Director of PT Bank Central Asia (BCA) stated that digitalization is not an option but a necessity for banks to fulfill the need for ease of transactions for their customers (Jayaatmaja, Rachmawati, and Saudi, 2020). Currently, there are at least four types of digital 
banking services that are widely known to the public, i.e. internet banking, phone banking, SMS banking, mobile banking (Mbama and Ezepue, 2018). However, customers' needs for ease of transactions continue to encourage banks to bring innovation through the development of digital banking services, especially those that focus on payment services (Bratadharma, 2017).

Innovations in banking services encourage the emergence of a new digital sector in the financial world known as fintech. Fintech is a combination of finance and technology that aims to make it easy to access financial products, conduct transactions, and increase literacy in the financial world. Quoted from finansialku.com (2020) there are several types of fintech categories, i.e. lending, financial planning (personal finance), retail investment, financing (crowdfunding), financial research, and payments.

One of the currently trending and widely discussed fintech innovations in the community is digital payment innovation. Companies are starting to realize the high potential of digital payments and that they must provide fintech services to meet the needs of their consumers (Sung, Leong, Sironi, O’Reilly, and McMillan, 2019).

Seeing all the opportunities and threats from the fintech industry in Indonesia which is starting to take share in the banking market (Sung et al., 2019), Himbara or the Association of Government-Owned Banks creates a better and more complete payment instrument for the public. Collaborating with Telkomsel, which also plays in the digital payment industry with the Tcash brand, they present LinkAja, which is a digital application-based payment system (Reskyana and Candiwan, 2020). LinkAja accommodates almost all choices of digital payment systems by stateowned banks and Telkomsel from e-cash systems to using QR codes. LinkAja is managed by PT Fintech Karya Nusantara owned by Telkomsel and is one of the steps to support the government in creating a cashless society (Fikri and Lisdayanti, 2020).

LinkAja was officially launched in Indonesia in March 2019. LinkAja is officially a digital payment instrument owned by a BUMN (state-owned bank). Utilizing the BUMN-owned business network, LinkAja is expected to be able to reach a wider range of users even to remote parts of Indonesia. One of LinkAja's advantages over other competitors is that LinkAja users can use savings or credit cards as a source of funds.

LinkAja targeted their marketing efforts on online game players in Indonesia, therefore researchers choose the Mobile Legend Online Gamers Community in Indonesia as the population, with the research objective to analyze the effect of eWOM on the decision to use digital wallet service application LinAja of the online gamers community members. The analysis were carried out by testing hypotheses based on several previous studies, i.e. research conducted by Ramadhani (2015) regarding "The Effect of Electronic Word of Mouth on Purchasing Decisions in 
Surabaya, Case Studies on Zalora and BerryBenka Online Stores". Where the research results reveal that the Electronic Word of Mouth has a significant influence on the purchasing decision process, especially on the content dimension which has a more dominant influence. Ramadhani (2015), also in their research on "The Effect of Online Reviews and Online Customer Ratings on Purchasing Decisions through the Market Place Shopee", revealed that online reviews and online ratings have a positive influence on purchase decisions. This study is relevant and important regarding to the limitations of literature on the effect of e-WOM in the context of digital payment products usage decision.

\section{Theoritical Framework of the Study}

\subsection{Consumer Behaviour in Digital Era}

Changes in consumer behavior in the digital era have become the main orientation in shifting the application of the current marketing system and brand marketing communication activities (Kotler, Kartajaya, et al., 2016). The study of consumer behavior is oriented toward individual or group patterns that form behavior to make decisions that aim to fulfill a set of needs and desires by empowering or utilizing existing resources such as money, energy, and time (Vázquez et al., 2014).

The rapid development of digital technology in the era of the digital economy has significantly changed consumer behavior (Briandana and Dwityas, 2020; Geni, Briandana, and Umarella, 2021; Manser Payne, Peltier, and Barger, 2017). Increasingly complex consumer needs make consumers more active and smarter in choosing digital products and services according to their wishes (Ertimur and Coskuner-Balli, 2015). Specifically in the digital era, there are consumer needs that do not change, but are sharpened or weakened by technology (Briandana, Doktoralina, Hassan, and Wan Hasan, 2020). For example, consumers want services that are tailored to their personalities (customization), social interaction, diversity of channel choices with access anytime anywhere, competitive value that is served by brands to them, as well as the desire for flexibility in making better choices because information is increasingly diverse and easy to obtain (Bakirtas and Akpolat, 2018).

In the context of product consumption, consumer behavior in the digital era is active and reactive, or interactive in seeking information related to brands (Bakirtas and Akpolat, 2018; Dwityas and Briandana, 2017). Consumers also become very mature and full of consideration in seeing the products to be purchased (Prisgunanto, 2014). This is made possible by the flood of information provided by various online channels and sources, so that consumers have the flexibility to search for detailed information and compare carefully between one brand and another that catches their attention (Ertimur and Coskuner-Balli, 2015).

Among the various sources and types of information available online, in fact many purchasing decisions occur due to the influence of word-of-mouth or advocacy from 
fellow users or what is commonly referred to as user generated content (Manser Payne et al., 2017). Consumers who get interesting experiences from a brand will be happy to tell and even recommend the brand to other consumers (Ghosh, Shah, and Swami, 2018). On the other hand, dissatisfied consumers are a boomerang for the brand's success in the market. These are two forms of advocacy, i.e. negative advocacy and positive advocacy. Connectivity paves the way for consumers to share their opinion on a brand. This connectivity provides a conducive climate for consumer advocacy practices for brands.

\subsection{Decision Making Process as Part of the Concept of Consumer Behavior}

Cultural, social, personal, and psychological factors have a very large influence on consumer purchasing behavior (Kotler, Keller et al., 2016). In addition, the level of consumer involvement and product uniqueness can also influence consumer purchasing behavior (Kotler, Keller et al., 2016). There are four types of consumer purchasing behavior which are differentiated by the level of involvement and the number of different types of brands (Kotler, Keller et al., 2016), such as: 1) complex purchasing behavior; 2) dissonance reduction purchasing behavior; 3) habitual purchasing behavior 4) diversity seeking purchasing behavior.

Based on the above consumer buying behavior, it can be concluded that consumers must go through several processes before deciding to buy a product. This process is known as the purchase decision process (Kotler, Keller et al., 2016).

\subsection{Electronic Word of Mouth as a Result of Post Purchase Evaluation in the Digital Era}

Electronic word of mouth according to Hennig-Thurau et al. (2004) is a statement either negative or positive made by a potential customer someone who is already a customer and a former customer regarding a product or company that is available to many people or institutions via the internet. According to Cheung and Thadani (2012), electronic word of mouth is a communication medium to share information about products or services that have been consumed or used with consumers who do not know or have never met before.

Based on the literature study above, it can be concluded that electronic word of mouth is a form of post-purchase evaluation in the digital era. Both of these activities have the same characteristics, i.e. in the form of information, containing negative or positive reviews of a product, channeled through the internet media and this information can be used by other consumers to determine the quality of a product (Hennig-Thurau et al., 2004).

\subsection{Research Hypothesis}

Research hypotheses help the researcher to focus on the research objectives and 
avoid distracting variables. The hypothesis is defined as a formal question about the relationship between the variables being tested directly. The hypothesis is divided into two, i.e., the null hypothesis and the research hypothesis. The null hypothesis is a logical alternative to the research hypothesis which states that there are differences in the relationship found. Based on the above thought framework, the researcher determines the following hypothesis:

$H O=$ Electronic Word of Mouth has no effect on the process of making transaction decisions using the LinkAja Application.

$H 1$ = Electronic Word of Mouth has an influence on the process of making transaction decisions using the LinkAja Application.

\section{Research Methodology}

To identify and measure the effect of electronic word of mouth on purchasing decisions, this study was conducted with an explanative quantitative approach (Sugiyono, 2012).

Research Subject: The subject of the current research is the millennial generation of members of the Facebook Mobile Legend: Bang Bang Indonesia community, with the population of 64 thousand people.

Data Collection Technique: The survey method was used to obtain primary data from the research sample. Sampling was done by using purposive sampling technique. Based on calculations using the Slovin formula, the minimum number of samples is 100 people and from the results of data collection, the research sample is 102 people. The instrument in this study was built from two variables, i.e., electronic word of mouth as the independent variable and decision to use as the dependent variable.

Electronic word of mouth has the following four dimensions: 1) intensity; 2) positive opinion; 3) negative opinion, and 4) content. There are several indicators on the electronic word of mouth variable: 1) intensity of accessing comments about LinkAja through internet media; 2) intensity of searching for information about LinkAja; 3) finding recommendations regarding LinkAja on internet media; 4) positive comments regarding the ease of transactions with LinkAja on the Internet.

Furthermore, the decision to use something has the following five dimensions: 1) recognition of needs; 2) information search; 3) evaluation of alternatives; 4) transaction decisions, and 5) post-use behavior. There are 21 (twenty one) indicators on the decision to use variable: 1) the desire to use LinkAja when viewing the promotional programs, discounts and cashback LinkAja Through the internet; 2) the desire to use LinkAja after seeing advertisements from internet media.

The validity test was carried out in two stages, i.e., the first test was on the validity 
of the instrument and the second test was to determine the validity level of the questions from the research instrument that had been filled in by 102 research respondents. With a total sample size of $102(\mathrm{df}=\mathrm{n}-2)$, the $\mathrm{r}$ product moment with a significance level of $5 \%$ is 0.194 . The electronic word of mouth variable is declared valid with $\mathrm{r}$ Pearson product moment for each indicator $>0.194$ and a significance level of $<0.05$.

Likewise, the decision to use variable is declared valid with $\mathrm{r}$ Pearson product moment for each indicator $>0.194$ and a significance level $<0.05$. From the results of the reliability test, it is known that the electronic word of mouth variable has a Cronbach alpha value of 0.841 above 0.70 and the decision to use variable has a Cronbach alpha value of 0.932 above 0.70 . Therefore, the electronic word of mouth variable and the decision to use variable are declared reliable.

Furthermore, the skewness and kurtosis tests were used to test for normality. In the electronic word of mouth variable, the skewness test obtained a value of $-2.58<\mathrm{Z}$ Skewness $=-2.40<+2.58$ and the curatorial test obtained a value of $-2.58<\mathrm{Z}$ Kurtosis $=1.31<+2.58$. This means that the electronic word of mouth variable has a normal data distribution. Thus, for the decision variable using the skewness test, the value was $-2.58<\mathrm{Z}$ Skewness $=-1.82<+2.58$ and the curatorial test obtained the value $-2.58<\mathrm{Z}$ Kurtosis $=0.52<+2.58$, meaning that the decision to use variable has a normal data distribution.

The results of the linearity test show that the electronic word of mouth variable with the decision to use variable has a linear relationship, the sig linearity value of electronic word of mouth data and the decision to use is 0.00 (less than 0.05). Likewise, the value of deviation from linearity is 0.366 (greater than 0.05 ).

\section{Result and Discussion}

The hypothesis in this study is "electronic word of mouth has an influence on the decision making process in transactions using the LinkAja application". To answer this hypothesis, a regression test was conducted which was preceded by a correlation test. From the results of the correlation test, it is known that there is a positive and significant relationship between electronic word of mouth and the decision to use with a relationship strength of 0.628 (level of correlation is "strong").

Table 1. Correlation Analysis Test Results

\begin{tabular}{|l|l|l|l|}
\hline \multicolumn{2}{|l|}{ Variable } & E_WOM & $\begin{array}{l}\text { Buying_ } \\
\text { decision }\end{array}$ \\
\hline \multirow{4}{*}{ E_WOM } & $\begin{array}{l}\text { Pearson } \\
\text { Correlation }\end{array}$ & 1 & $.628^{* *}$ \\
\cline { 2 - 4 } & Sig. (2-tailed) & & 0.000 \\
\cline { 2 - 4 } & N & 102 & 102 \\
\hline Buying & Pearson & $.628^{* *}$ & 1 \\
\hline
\end{tabular}




\begin{tabular}{|l|l|l|l|}
\hline decision & Correlation & & \\
\cline { 2 - 4 } & Sig. (2-tailed) & 0.000 & \\
\cline { 2 - 4 } & $\mathrm{N}$ & 102 & 102 \\
\hline
\end{tabular}

Source: Own study.

Furthermore, from the results of the $t$ test, it is known that the electronic word of mouth variable has a significance value of $0.000(<0.05)$. This means that it has an influence on the decision to use. Then from the test results of the level of significance of the relationship between variables, it is known that the $t_{\text {count }}$ value is above the $\mathrm{t}_{\text {table }}$ value, which is $8.079>1.984$. This means that the research hypothesis is acceptable, and there is an influence between electronic word of mouth on the decision to use the LinkAja application.

Table 2. T Test Results

\begin{tabular}{|c|c|c|c|c|c|c|}
\hline \multirow{2}{*}{ Model } & \multicolumn{2}{|c|}{$\begin{array}{c}\text { Unstandardized } \\
\text { Coefficients }\end{array}$} & $\begin{array}{c}\text { Standardize } \\
\text { d } \\
\text { Coefficients }\end{array}$ & \multirow{2}{*}{ t } & \multirow{2}{*}{ Sig. } \\
\cline { 3 - 5 } & \multicolumn{2}{|c|}{ B } & Std. Error & Beta & & \\
\hline 1 & (Constant) & 1.037 & 0.334 & & 3.101 & 0.003 \\
\hline & E_WOM & 0.700 & 0.087 & 0.628 & 8.079 & 0.000 \\
\hline
\end{tabular}

a. Dependent Variable: Keputusan_pembelian

Source: Own study.

Table 3. Determination Coefficients

\begin{tabular}{|c|c|c|c|c|}
\hline & & & Adjusted & $\begin{array}{c}\text { Std. Error } \\
\text { of the } \\
\text { Estimate }\end{array}$ \\
\hline 1 & $.628^{\mathrm{a}}$ & 0.395 & 0.389 & 0.519 \\
\hline
\end{tabular}

\section{a. Predictors: (Constant), E_WOM}

Source: Own study.

Judging from the coefficient of determination, it is known that there is $39.5 \%$ contribution of electronic word of mouth to use decisions and $60.50 \%$ is influenced by other factors. It is also known that the more electronic word of mouth increases, the more the decision to use increases.

The hypothesis built in this study is "electronic word of mouth has an influence on the decision making process for transactions using the LinkAja application". Based 
on the results of the regression test, it is known that there is a significant effect of electronic word of mouth on the process of making transaction decisions using LinkAja. Therefore, the proposed hypothesis can be accepted.

The results of this study are in line with previous studies conducted by Ardianti and Widiartanto (2019) dan Ivana et al., (2014) even though there is a difference in the percentage of the contribution of independent variables to the dependent variable. This study has a higher percentage contribution than Ardianti and Widiartanto (2019) study and the percentage contribution is lower than the study of Adeliasari (2014).

From the descriptive test results on the research variables, it is known that the respondents gave a positive response with a high category on the electronic word of mouth variable and the decision to use variable. The test results are in line with the results of the correlation test, where it is known that electronic word of mouth has a strong relationship with the decision to use. However, the value of electronic word of mouth's contribution to use decisions only reached $39.5 \%$.

If further analyzed by looking at the relationship between dimensions, it is known that there is an insignificant relationship in the dimension of "negative opinion" electronic word of mouth variable with all dimensions in the decision to use variable. This finding is in line with the respondent's response, where the response with the lowest positive response from the electronic word of mouth variable is in the "negative opinion" dimension, i.e., the negative opinions of LinkAja users read by the respondent. This negative opinion includes comments containing the disappointment of LinkAja users, including about the use of the LinkAja application, cashback constraints, and timing of top ups.

When compared with the response to the dimension of "negative opinion", the positive response to the dimension of "positive opinion" has a greater percentage. This indicates that respondents saw or were exposed to positive comments more than negative comments. The positive opinions seen by respondents about LinkAja include the ease of transactions, the value of discounts and cashback, and recommendations for using LinkAja. Related to this, it is important for LinkAja to maintain and improve service quality considering that when consumers are more and more exposed to negative information, it will damage the consumer's view of a product (Kotler, Kartajaya, et al., 2016).

Furthermore, the highest positive responses from respondents were toward the content dimension where respondents could easily find reviews about LinkAja, easily find specials, and easily find information about the features provided by LinkAja. This finding is consistent with the relationship between dimensions, where the relationship with the highest value of closeness was found to fall within the "strong" category, i.e. the relationship between the "content" dimension and the "need recognition" dimension. The content provided by Link Aja can help 
respondents identify their needs so that respondents have the desire to use the LinkAja application.

The relationship between dimensions that have other "strong" relationship categories is between the "intensity" dimension and the "transaction decision" dimension. Frequently respondents find content about the recommendations and comments of the LinkAja application users to have a strong relationship with the decision to use the LinkAja application. Driven by the adequacy of information obtained through the recommendations and comments of LinkAja users, respondents tried to use the Link Aja application and felt that the LinkAja application was easy and fast to use for transactions. The features offered could meet the needs and were also supported by the promos offered.

Furthermore, in the decision variable the use of positive responses from respondents with the lowest presentation is on the dimension of "post-use behavior", especially in providing recommendations and positive opinions on social media. Although the majority of respondents are satisfied using the LinkAja application, they have not been able to encourage respondents to provide positive opinions or recommendations. It is also necessary to get attention with the not optimal participation of respondents to give positive opinions and recommends LinkAja on social media. There are respondents who give negative opinions on social media about LinkAja, especially about difficulties in doing transaction on the LinkAja application.

An important finding from this study is that the intensity of accessing information both to find out recommendations and comments from LinkAja users is the main driving factor for respondents in the process of recognizing their needs and in the process of making decisions to use the LinkAja application. However, other findings show that respondents who are satisfied using the LinkAja application have not been optimally motivated to provide recommendations or positive comments on social media, especially within the Facebook community of Mobile Legend: Bang Bang Indonesia.

\section{Conclusion and Recomendations}

This study concludes that electronic word of mouth has a strong and positive relationship to the decision making process for transactions using the LinkAja application. The research hypothesis proposed in this study can be accepted or it can be concluded that electronic word of mouth has an influence on the decision-making process of transactions using the LinkAja application. The influence generated by electronic word of mouth on the decision-making process of transactions using the LinkAja application is known to be $39.50 \%$ and the remaining $60.50 \%$ is influenced by other factors. It is known that the internet is the dominant source for the majority of respondents to obtain information about the LinkAja application and information obtained via the internet is considered capable of meeting the respondent's needs. 
This statement is the result of the analysis on the distribution of responses on the content dimension as the dimension with the highest distribution.

Meanwhile, from the analysis carried out on the lowest dimension of the electronic word of mouth variable, it is known that the less respondents are exposed to negative information, the better their views on the LinkAja application. It is known that respondents involve more than one factor in evaluating alternatives. The first factor is information obtained via the internet or electronic word of mouth and personal factors. In which it is known that electronic word of mouth is a factor that has a more dominant influence on alternative evaluation as a dimension with the highest positive response to purchasing decision variable.

From the lowest dimension, i.e., the post-use evaluation dimension, it is concluded that there are two possibilities that cause the low distribution of positive responses on this dimension. These possibilities are because there are still many consumers who decide not to tell their experiences or it turns out that respondents do not use the LinkAja application so they cannot evaluate on the LinkAja application.

\section{References:}

Al-Dmour, H.H., Asfour, F., Al-Dmour, R., Al-Dmour, A. 2020. The Effect of Marketing Knowledge Management on Bank Performance Through Fintech Innovations: A Survey Study of Jordanian Commercial Banks. Interdisciplinary Journal of Information, Knowledge, and Management, 15, 203-225.

Ardianti, A.N., Widiartanto, W. 2019. Pengaruh Online Customer Review dan Online Customer Rating terhadap Keputusan Pembelian melalui Marketplace Shopee.(Studi pada Mahasiswa Aktif FISIP Undip). Jurnal Ilmu Administrasi Bisnis, 8(2), 55-66.

Bakirtas, T., Akpolat, A.G. 2018. The relationship between energy consumption, urbanization, and economic growth in new emerging-market countries. Energy, 147, 110-121.

Bohang, F.K. 2018. Berapa jumlah pengguna internet Indonesia? Kompas. com.

Bratadharma, A. 2017. Menaikkan Kelas UMKM Demi Perekonomian Indonesia. Metronews, June, p. 9.

Briandana, R., Doktoralina, C.M., Hassan, S.A., Wan Hasan, W.N. 2020. Da'wah Communication and Social Media: The Interpretation of Millennials in Southeast Asia. International Journal of Economics and Business Administration, VIII(Special Issue 1), 216-226. https://doi.org/10.35808/ijeba/543.

Briandana, R., Dwityas, N.A. 2020. Conventional marketing communication tools for residential products in digital era. Technium: Social Science Journal, 14(1), 193-205.

Chan, A.S., Fachrizal, F., Lubis, A.R. 2020. Outcome Prediction Using Naïve Bayes Algorithm in The Selection of Role Hero Mobile Legend. In Journal of Physics: Conference Series, 1566, 12041. IOP Publishing.

Cheung, C.M.K., Thadani, D.R. 2012. The impact of electronic word-of-mouth communication: A literature analysis and integrative model. Decision Support Systems, 54(1), 461-470.

Dasho, A., Meka, E., Sharko, G., Baholli, I. 2016. Digital banking the wave of the future. Proceedings of ISTI 2016, 1, 1-6. 


\section{eWom and Decision Making on the Use of E-Wallet Application By Indonesian Customer}

Dwityas, N.A., Briandana, R. 2017. Social media in travel decision making process. International Journal of Humanities and Social Sciences, 7(7), 291-292.

Dwityas, N.A., Mulyana, A., Hesti, S., Briandana, R., Putrianti, M.K. 2020. Digital Marketing Communication Strategies: The Case of Indonesian News' Portals. International Journal of Economics and Business Administration, 8(3), 307-316. https://doi.org/10.35808/ijeba/517.

Eckhardt, G.M., Houston, M.B., Jiang, B., Lamberton, C., Rindfleisch, A., Zervas, G. 2019. Marketing in the sharing economy. Journal of Marketing, 83(5), 5-27.

Ertimur, B., Coskuner-Balli, G. 2015. Navigating the institutional logics of markets: Implications for strategic brand management. Journal of Marketing, 79(2), 40-61.

Fan, L., Liu, X., Wang, B., Wang, L. 2017. Interactivity, engagement, and technology dependence: understanding users' technology utilisation behaviour. Behaviour \& Information Technology, 36(2), 113-124.

Fan, Y.W., Miao, Y.F. 2012. Effect of electronic word-of-mouth on consumer purchase intention: The perspective of gender differences. International Journal of Electronic Business Management, 10(3), 175.

Fikri, M., Lisdayanti, A. 2020. Analysing Promotion Mix and Perceived Usefulness of eWallets: A case of Linkaja applications in Indonesia. International Journal of Finance \& Banking Studies, 9(1), 76-84.

Geni, G.L., Briandana, R., Umarella, F.H. 2021. The Strategies of Television Broadcast During the Covid-19 Pandemic: A Case Study on Indonesian Television. Malaysian Journal of Communication, 37(2), 243-256. https://doi.org/https://doi.org/10.17576/JKMJC-2021-3702-15.

Ghosh, D., Shah, J., Swami, S. 2018. Product greening and pricing strategies of firms under green sensitive consumer demand and environmental regulations. Annals of Operations Research, 1-30.

Goldsmith, R.E., Horowitz, D. 2006. Measuring motivations for online opinion seeking. Journal of Interactive Advertising, 6(2), 2-14.

Gosta, D.R., Utami, D.N., Dewi, F.S. 2018. Presiden direktur PT Visionet internasional (ovo), Adrian Suherman: jangan bersaing, mending kerja sama.

Hammerschlag, Z., Bick, G., Luiz, J.M. 2020. The internationalization of African fintech firms: marketing strategies for successful intra-Africa expansion. International Marketing Review.

Hennig-Thurau, T., Gwinner, K.P., Walsh, G., Gremler, D.D. 2004. Electronic word-ofmouth via consumer-opinion platforms: what motivates consumers to articulate themselves on the internet? Journal of Interactive Marketing, 18(1), 38-52.

Homsi, D.M.D.A., Hashem, T.N., Freihat, S.M. 2020. How can entrepreneurial marketing promote the entrepreneurship culture in an organization: Case of banking sector in Jordan. Innovative Marketing, 16(1), 29-42. https://doi.org/10.21511/im.16(1).2020.04.

Ivana, V., Sari, A., Thio, S. 2014. Electronic Word-of-mouth (E-wom) Dan Pengaruhnya Terhadap Keputusan Pembelian Di Restoran Dan Kafe Di Surabaya. Jurnal Hospitality Dan Manajemen Jasa, 2(2), 218-230.

Jalilvand, M.R., Esfahani, S.S., Samiei, N. 2011. Electronic word-of-mouth: Challenges and opportunities. Procedia Computer Science, 3(2), 42-46.

Jayaatmaja, M.A., Rachmawati, R., Saudi, M.H.M. 2020. What Happened to Indonesia SOEs Governance? International Journal of Psychosocial Rehabilitation, 24(02), 3443-3449.

Kamboj, S., Sarmah, B., Gupta, S., Dwivedi, Y. 2018. Examining branding co-creation in brand communities on social media: Applying the paradigm of Stimulus-OrganismResponse. International Journal of Information Management, 39, 169-185. 
Kotler, P., Kartajaya, H., Setiawan, I. 2016. Marketing 4.0: Moving from traditional to digital. Hoboken, New Jersey: John Wiley \& Sons.

Kotler, P., Keller, K.L., Brady, M., Goodman, M., Hansen, T. 2016. Marketing management. New York: Pearson Education Ltd.

Liu, S., Jiang, C., Lin, Z., Ding, Y., Duan, R., Xu, Z. 2015. Identifying effective influencers based on trust for electronic word-of-mouth marketing: A domain-aware approach. Information Sciences, 306(4), 34-52.

Luthfi, A. 2019. Juta Anak Milenial Gemar Bermain Game Setiap Hari. Retrieved from OKEZONE TV: Https://Techno. Okezone. Com/Read/2019/03/28/326/2036223/30Juta-Anak-Milenial-Gemar-Bermain-Game-Setiap-Hari.

Manser Payne, E., Peltier, J.W., Barger, V.A. 2017. Omni-channel marketing, integrated marketing communications and consumer engagement: A research agenda. Journal of Research in Interactive Marketing, 11(2), 185-197.

Mbama, C.I., Ezepue, P.O. 2018. Digital banking, customer experience and bank financial performance. International Journal of Bank Marketing.

Rachmawati, D., Shukri, S., Azam, S., Khatibi, A. 2019. Factors influencing customers' purchase decision of residential property in Selangor, Malaysia. Management Science Letters, 9(9), 1341-1348.

Ramadhani, B. 2015. Pengaruh Electronic Word of Mouth (E-WoM) Terhadap Keputusan Pembelian di Surabaya (Studi terhadap Toko Online Zalora dan BerryBenka). STIE PERBANAS SURABAYA.

Reskyana, N., Candiwan, C. 2020. Analysis of Factors Affecting Continuance Usage Intention of Linkaja Applications. Almana: Jurnal Manajemen Dan Bisnis, 4(1), 17-28.

Shaikh, A.A., Glavee-Geo, R., Karjaluoto, H. 2017. Exploring the nexus between financial sector reforms and the emergence of digital banking culture-Evidences from a developing country. Research in International Business and Finance, 42, 1030-1039.

Sugiyono, M. 2012. Metode Penelitian Kuantitatif, Kualitatif, dan Kombinasi. Bandung: Alfabeta.

Sung, A., Leong, K., Sironi, P., O’Reilly, T., McMillan, A. 2019. An exploratory study of the FinTech (Financial Technology) education and retraining in UK. Journal of WorkApplied Management.

Vázquez, S., Muñoz-García, Ó., Campanella, I., Poch, M., Fisas, B., Bel, N., Andreu, G. 2014. A classification of user-generated content into consumer decision journey stages. Neural Networks, 58, 68-81.

Zahay, D. 2015. Digital Marketing Management - A Handbook for the Current (or Future) CEO. Chennai: Business Expert Press. 